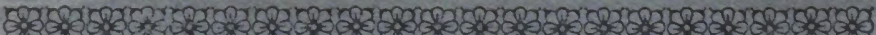

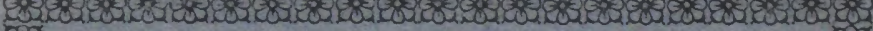

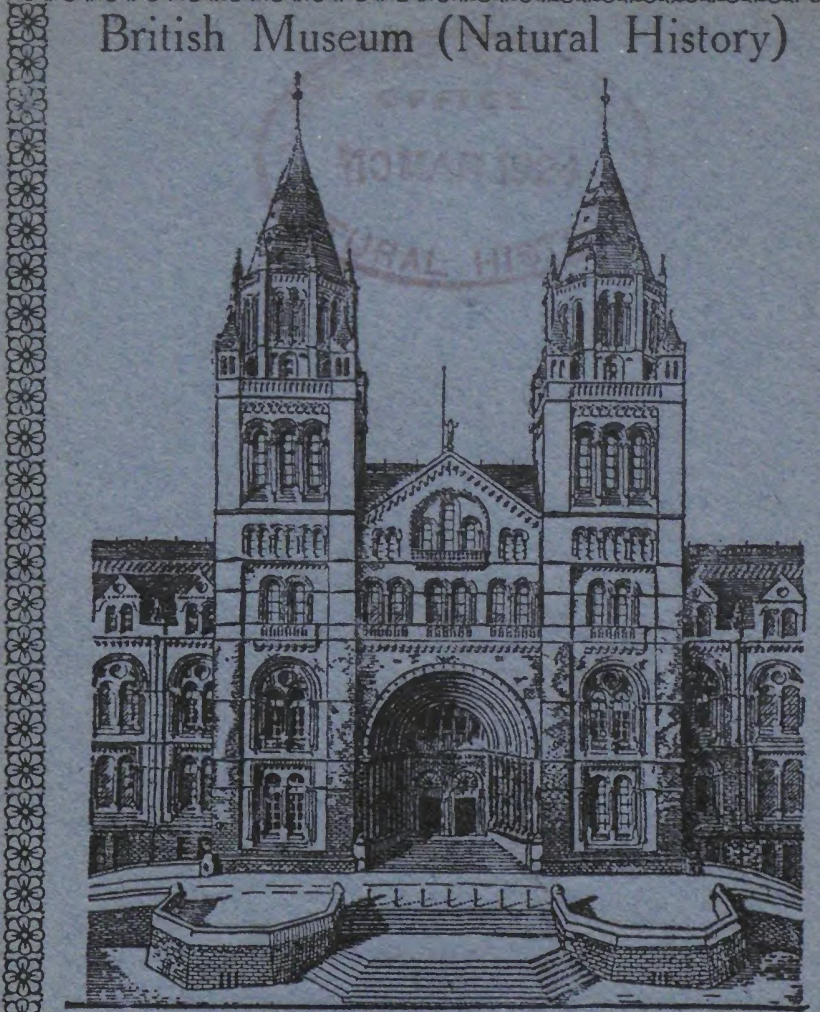
EXOTIC GRASSHOPPERS AND

.

8

8

$$
\begin{gathered}
\text { PRAYING INSECTS } \\
\text { (ORTHOPTERA) } \\
5 \text { Cards in Colour }
\end{gathered}
$$




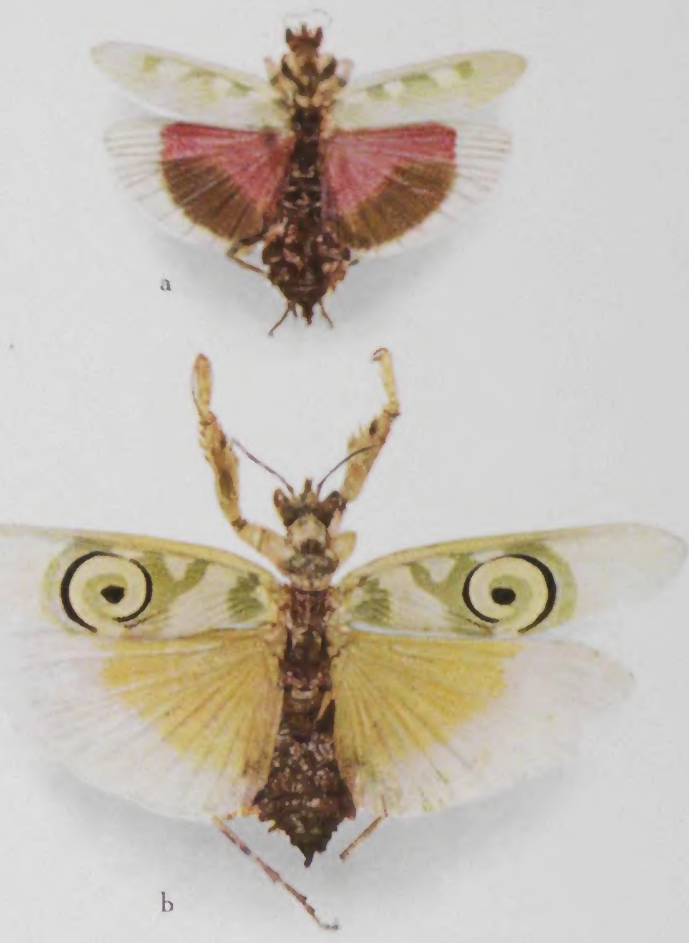




\section{POST CARD.}

ThIS SPACE MAY RE USED FOR PRINTED OR WRITTEN MatTer,
THE ADDRESS ONLY TO HB WRITTEN HERB 

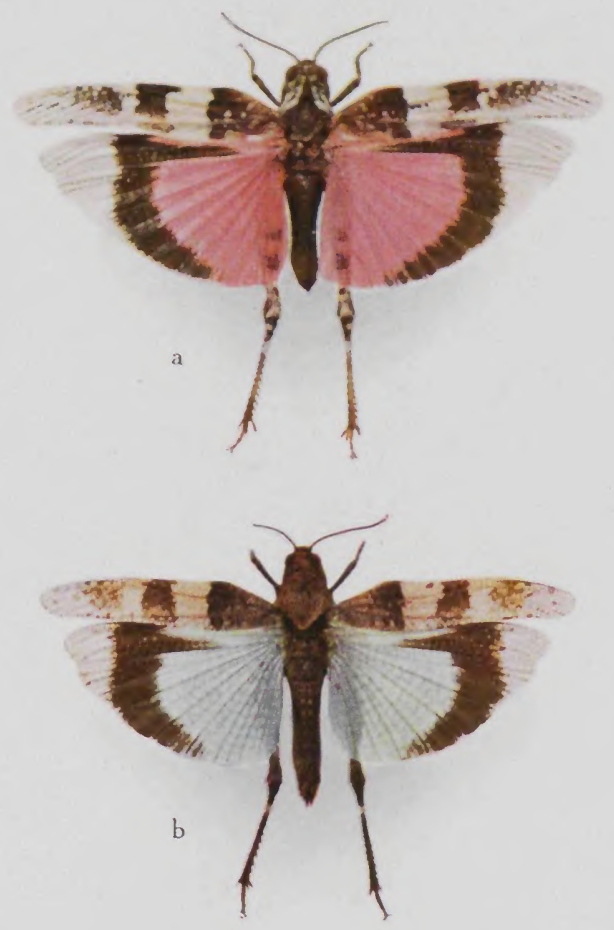

EXOTIC ORTHOPTERA

Grasshoppers

(a) Oedipoda miniata (b) Oedipoda carulescens

Natural size

British MLseum (Natural. History) 


\section{POST CARD.}

THIS SFACE MAV RE USRD FOR PRINTED OR WRITTEN MATTRR.
THE ADDRESS ONI.V TO $\mathrm{BH}$ WRITTEN HRKE 


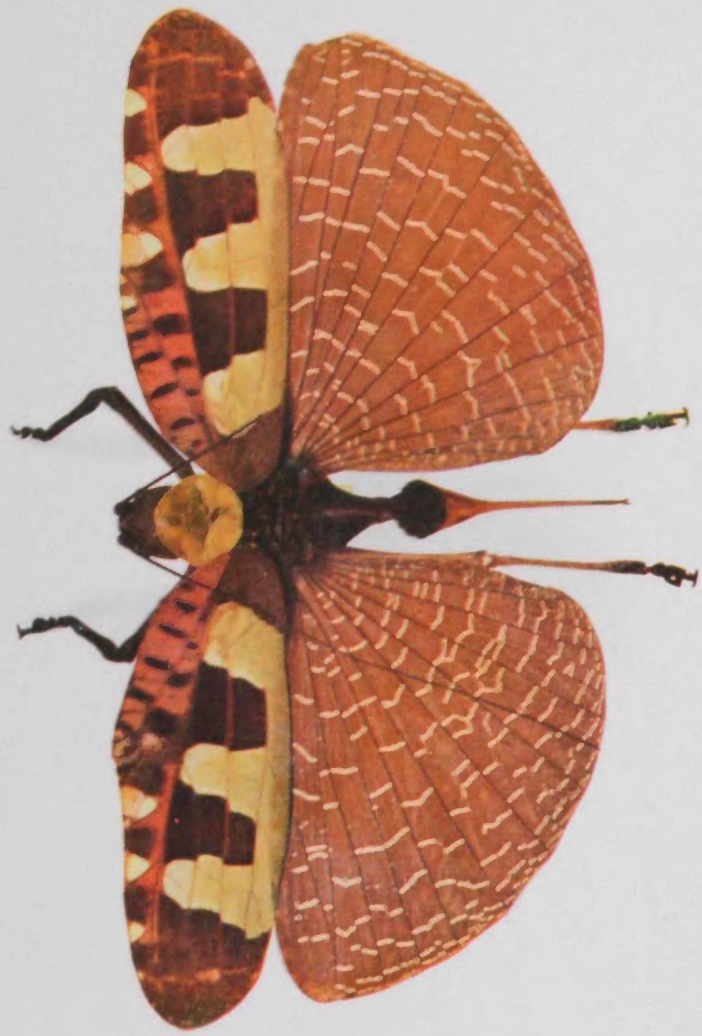

EXOTIC ORTHOPTERA

Grasshopper

Sanaa imperialis

Natural size

British Museum (Naturai. History) 


\section{POST CARD.}

THIS SYRCE MA: BE CSRD FOR PRIXTED OR WRITTEN MATTER.
THE ADDRFSS ONYY TO RE WRITTES HERE 

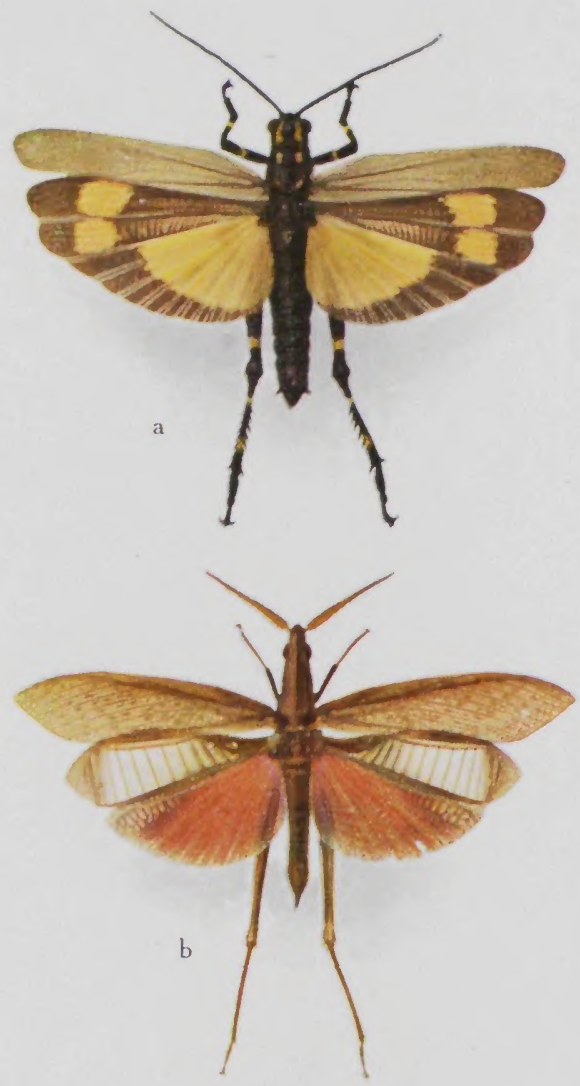

EXOTIC ORTHOPTERA

Grasshoppers

(a) Chromacris miles (b) Hyalopteryx rufipennis

Natural size

BrtTish Musteun (NATURal. History) 


\section{POST CARD.}

This SPACE MAY Re USED FOR PRINTED OK WRITteN MATTKK.
THE ADDRESS ONIY TO HE WRITTEN HERE
STAVP. 


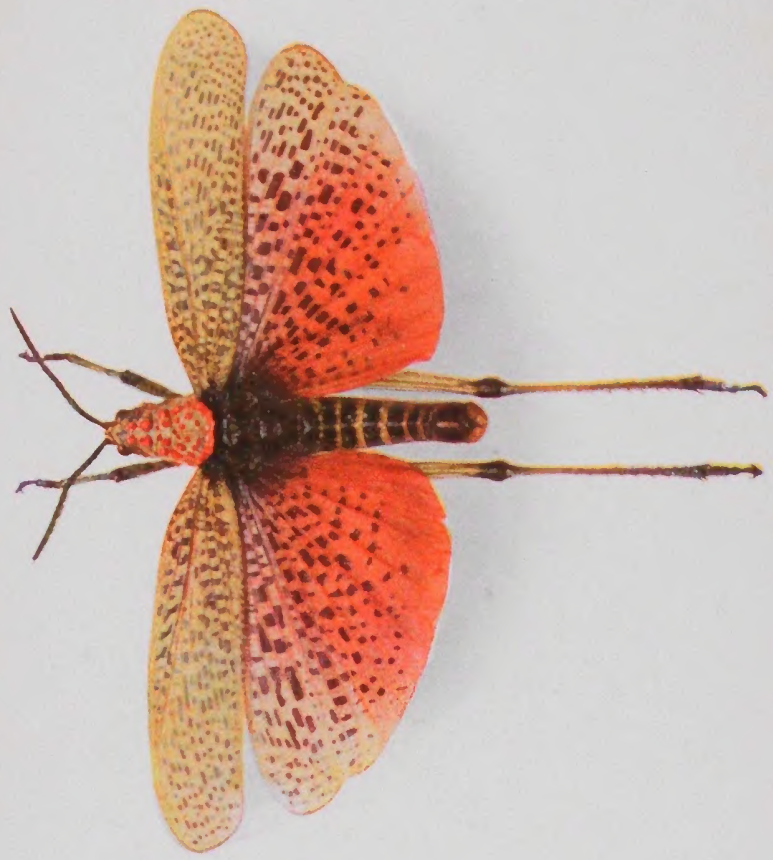

EXOTIC ORTHOPTERA

Grasshopper

phymateus moibillosus

Natural size

Britigh Museum (Natura, History)

Produced by W. 1:. Sedgwick, Limited 


\section{POST CARD.}

ThIS SPACR MAV AR USFD FOR PRINTED OK WRITTEN MATTER.
THR AHWRESSONLY TO NM WRITISN HORR
S1.111P. 


\section{BRITISH MUSEUM (NATURAL HISTORY).}

\section{EXOTIC GRASSHOPPERS AND PRAYING-INSECTS (ORTHOPTERA).}

The five cards in this series illustrate some insects of the order Orthoptera. This order comprises Cockroaches (Blattida), Prayinginsects (Mantidæ), Stick-insects (Phasmidæ), Locusts and other short-horned grasshoppers (Acrididæ), long-horned grasshoppers (Tettigoniida) and Crickets (Gryllidæ). Variation in gcneral appearance, in type of coloration, and in habits, is very great among the several families of Orthoptera, but they all have in common powcrful biting jaws, two pairs of wings (sometimes undeveloped) in the adult stage, and an incompletc metamorphosis, i.e., the young larva when they emerge from the eggs are more or lcss likc the adults, but without wings. The wings appear at a later stage and grow gradually; and the transformation into the adult form takes place without a pupal stage. Some families are entirely flesh-eatcrs, such as Mantids, which prey on other insects; others (Acrididæand Phasmidæ)are invariably plant-eaters, and include many scrious pests to agriculture, such as the migratory locusts; others again prefer a mixed dict. 
E96. PRAYING-INSECTS (MANTIDA).

The Mantids are carnivorous insects preying upon other insects, which they catch with their heavily spined front legs, which are specially adapted for this purpose. Most of them are coloured green or brownish, and being concealed by this coloration when sitting on trees and bushes they wait for unsuspecting flies or other insects to approach. Their attitude while thus lying in wait for their prey is highly characteristic : the front part of the body is raised, and the fore legs, partially folded, are held together in front of the face, irresistibly suggesting the attitude of prayer. From this attitude is derived their popular name of "praying insects." The hind wings of some species are brightly coloured, but are concealed in repose.

The upper figure represents Harpagomantis discolor, from S. Africa; the lower one, Psendocreobotra wahlbergi, also from S. Africa, a species remarkable for the pattern of the front wings.

E 97. Sanaa imperialis, is one of the most exquisitely adorned long-horned grasshoppers (Tettigoniidx). Most of the members of the family are carnivorous, but some of them are mixed feeders. This species occurs only in Sikkim. 
E 98. Two short-horned grasshoppers (Acrididx) of the genus Oedipoda, which is restricted in its distribution to temperate regions of the Old World, are represented on this postcard. These insects inhabit localities with sparse vegetation, and when they sit on the ground with their wings folded they are very difficult to see, since the coloration of all the exposed parts matches that of the ground. Thus the insect in the upper figure (Oedipoda miniata) has been taken in Palestine in stony desert country, where outcrops of white limestone occur, and accordingly its coloration in repose is a combination of whitish and brown; white the lower figure shows a species (Oedipoda coerulescens) inhabiting Southern Europe, North Africa, and a large part of Asia, which is often found on clay soil. It is remarkable that the coloration of individuals of the same species is very variable, and these variations are generally in accordance with the prevaiting colour of the ground in each locality. The brilliantly coloured hind wings are conspicuous only when the insect flies; when it drops on the ground it is at once lost to sight.

E 99. Two very typical representatives of South American short-horned grasshoppers (Acrididx) are figured on this card. 
The upper figure is Chomacris miles from Brazil. The species is known to be dimorphic, that is, occurring in two colour forms, one with yellow hind wings, the other with red. The lower figure represents Hyalopteryx rufipennis, also from Brazil. It is a member of the subfamily Acridinæ (or Truxalinæ) in which the antennæ are often shaped like daggers. The significance of the remarkable hyaline (glassy) expansion of a portion of the hind wings is not known in this species, but in some other grasshoppers it functions as a resounding apparatus. to increase the clattering sound produced by the wings in flight.

E 100. This South African short-horned grasshopper, Phymateus morbillosus, belongs to a genus widely distributed in Africa and represented there by many strikingly coloured species. Some species of the genus are known to be able, when attacked, to discharge a foamy fluid from the special glands at the base of the abdomen : this is considered to be a means of defence against birds and other natural enemies of these insects.

Set E 16.

Febniary, 1924. 